\title{
A Contribution to the Critique of the Political Economy of Transnational Informational Capitalism
}

\section{Christian Fuchs}

\begin{abstract}
Concepts like knowledge society, information society, postmodern society, postindustrial society, Internet society, and network society fail to grasp the dialectic of the continuity and discontinuity of society. These concepts take the changes associated with new media as radical novelties and ignore the continuing dominance of capitalist structures. Contemporary capitalism is highly antagonistic and requires a dialectical analysis. Transnational network capitalism and transnational informational capitalism are used as key concepts for grasping the importance of information technologies and knowledge and their role in a transnational and flexible regime of accumulation. One important principle for gaining profit from information commodities is that goods are sold at prices that are much higher than their value.
\end{abstract}

Key Words: Knowledge, Information, Networks, Globalization, Transnational Informational Capitalism

Many social scientists agree that contemporary society has been undergoing important changes. However, there is not so much agreement on which concept best describes and grasps these changes. Although topics such as globalization and the role of the media and computer networks in society can be found in many contemporary social theories, there is much difference concerning selection of the key concept. Although social theories are complex as such, choosing one key concept means stressing certain factors that one considers particularly important and describing them as the fundamental influences that shape and change society. The question of which key concept best describes contemporary society is not trivial, but of high importance. A critical key concept is required as political practice is informed by the way academics describe social reality. There are a number of competing concepts, and Marxist ones are needed in order to pose alternatives to affirmative notions and to inform oppositional political practices.

The main task of this paper is to discuss micro- and macro- aspects of economic changes that are related to information and communication technologies (ICTs). The approach that is chosen is close to the Marxian critique of the political economy of media and communication. One reason I consider this approach superior to others is that it allows an analysis of contemporary society based on a dialectic of change and 
continuity, which avoids the pitfalls of assuming one-sided radical novelty or radical conservation in social theory. Another reason is that it questions the status quo and tries to show its antagonisms whereas uncritical theories affirm existing structures of domination.

I begin by discussing key concepts for conceptualizing contemporary society, and introduce the notion of transnational network/informational capitalism. I next outline the causes of contemporary societal changes, then discuss some important aspects and principles of capital accumulation with the help of information commodities and information technologies. Finally, I draw some conclusions.

\section{Conceptualizing Contemporary Society}

The dominant approaches that describe contemporary society are radically discontinuous. Such conceptions are uncritical and affirmative because they do not point toward problems and the negativity of contemporary society. These approaches are right in pointing out that networked forms of organization, digital networked information, communication technologies, and knowledge labor have become more important. My argument against such concepts is that they fail to show the negativity and class character of these transformations. They neglect domination, exploitation, power, and ideology (Fuchs 2008a).

Discontinuous concepts that have been utilized for describing contemporary society include the knowledge/information economy and postindustrial, postmodern, information, knowledge, and network society. These approaches will be contrasted with Marxian-inspired theories.

\section{Discontinuous Approaches}

Fritz Machlup (1962) introduced the concept of the knowledge industry. He distinguished five knowledge sectors: education, research and development, mass media, information technologies, and information services. Peter Drucker (1969) argued that there is a transition from an economy based on tangible goods to one based on knowledge. Marc Porat (1977) used the total value added by the primary and secondary information sector to the gross national product (GNP) as an indicator for the information economy. Based on Porat, Karl Deutsch defined the information society as a society in which more than half the GNP is produced and more than half the employees are engaged in the information economy (Deutsch 1983).

A number of authors defined the postindustrial or information society as one in which the majority of employees works in information or service jobs (Bell 1976, 348; Otto and Sonntag 1985; Stehr 1994, 2000a, 2000b). Alain Touraine alluded to postindustrial society in 1971 (cf. Touraine 1988, 104). Radovan Richta (1977) argued that society has been transformed into a scientific civilization that is based on services, education, and creative activities. In his opinion, science and technology are immediate forces of production. 
Jean-François Lyotard argued that, in postmodern society, "knowledge has become the principal force of production over the last few decades" $(1984,5)$. This development breaks up grand narratives as, due to the role of the economy, knowledge production is no longer the exclusive realm of science and ideology. Lyotard's notion of postmodern society agrees with Stehr's concept of the knowledge society and Toffler's category of the Third Wave economy in the assumption that knowledge has become the central resource in the economy (cf. Stehr 2002a; Dyson, Gilder, Keyworth, and Toffler 1994).

One of the most recent discontinuous concepts is that of the network society, which signifies the assumption that "networks constitute the new social morphology of our societies, and the diffusion of networking logic substantially modifies the operation and outcomes in processes of production, experience, power, and culture" (Castells 2000, 500, see also 21; Van Dijk 2006, 20; Barney 2004, 25 et seq.).

The problem underlying all these concepts is that they create the impression that we have entered a new type of society. "If there is just more information then it is hard to understand why anyone should suggest that we have before us something radically new" (Webster 2002a, 259). They stress discontinuity, as if contemporary society had nothing in common with society as it was 100 or 150 years ago. Such assumptions have an ideological character because they comply with the view that we can do nothing about change and have to adapt to existing political realities (Webster 2002b, 267). Peter Golding $(2000,170)$ argues that the information-society discourse is an ideology that "anticipates and celebrates the privatization of information, and the incorporation of ICT developments into the expansion of the free market." According to him, the danger in sociology's fascination with the new is that it distracts from a focus on radical potentials and the critique of how these potentials are suppressed (Golding 2000, 171). Contemporary society first of all is still a capitalist society oriented toward accumulating economic, political, and cultural capital. There is a dialectic of continuity and discontinuity; capitalist development has entered a new phase of development.

Nigel Thrift (2005) wrote a "critique" of what he terms soft capitalism or knowing capitalism. Capitalism is not used as a negative category in this approach. Thrift's "critique" is affirmative, not critical in a Marxian sense (the relations of capitalism "are not all bad," capitalism "is also fun. People get stuff from it," etc.). Although his approach is not discontinuous, it is as affirmative as discontinuous theories.

\section{Marxian Approaches}

I consider the approach of the critique of the political economy of communication and the media more suitable for analyzing contemporary society than theories of discontinuous development. The former addresses the negative role of the media in capitalism as commodity, ideology, marketing tools, tools for the reproduction of labor power, tools for domination, and antagonistic forces that also produce potentials for change through their operation (Fuchs 2008a, 2009; cf. Knoche 1999).

There is indeed, as theorists of radically discontinuous development argue, a rising importance of knowledge labor and services in the employment structure and in value 
production, and a transformation of the role of science, knowledge, and computer technology that have become immediate productive forces (Fuchs 2008a). But this is only one side of the story. The notion of transnational informational/network capitalism grasps as well the other side by stressing that these developments play a role in the accumulation of capital, hence also contribute to the creation and deepening of societal problems. This notion is similar to some other Marxist approaches, but also differs from them insofar as it tries to avoid focusing on either purely objective-technological or purely subjective factors.

Objective Marxist Approaches. For describing contemporary society, Marxist scholars have suggested terms that focus on transformation of the productive forces, like digital capitalism (Schiller 2000; see Glotz 1999 for a non-Marxist account), virtual capitalism (Dawson and Foster 1998, 63 et seq.), high-tech capitalism (Haug 2003), informatic capitalism (Fitzpatrick 2002), and communicative capitalism (Dean 2005). I prefer such terms to radical discontinuous terms like information society or postmodern society because the first contain a critical negativity. But they convey the impression that technology (digital, virtual, high technology) determines society: that is, that the relations of production are a linear result of the productive forces. Change in contemporary society affects forces and relations, structures and actions, because society is based on a dialectical dynamic of these two qualities (Fuchs 2008a). Hence I prefer to speak of knowledge capitalism, informational capitalism, or network capitalism in order to stress that both knowledge work and information technologies shape capital production and accumulation in contemporary society and are two interconnected qualities.

Subjective Marxist Approaches. Michael Hardt and Antonio Negri (2005) argue that contemporary society is an empire characterized by a singular global logic of capitalist domination based on immaterial labor. Based on Hardt and Negri's focus on immaterial labor, there are some Marxist approaches that frame the current transformation not as objective approaches in terms of technological transformation, but as a subjective turn. Carlo Vercellone (2007) sees the transformation of capitalism as a subjective turn and therefore speaks of "cognitive capitalism," a formation characterized by "the hegemony of knowledges, by a diffuse intellectuality, and by the driving role of the production of knowledges by means of knowledges connected to the increasingly immaterial and cognitive character of labor" (Vercellone 2007, 16). There would be a "preponderance of the knowledges of living labor over knowledges incorporated in fixed capital and in corporate organization" (32). For Vercellone, the emerging antagonism between the living knowledge of labor and the dead knowledge of fixed constant capital causes a crisis of the law of value and an antagonism between capital's attempt to enforce the law of value artificially (e.g., by intellectual property rights) and the socialization of knowledge by its incorporation in the brains of the collective workers of the general intellect. Paolo Virno (2004) formulates this assumption as his thesis number seven, which says that in post-Fordism, the general intellect does not 
coincide with fixed capital but manifests itself principally as a linguistic reiteration of living labor. That the role of technology does not vanish, as claimed by Vercellone, can be seen by the fact that among the 100 largest corporations worldwide (measured by a composite index of sales, market value, assets, and profits, such as the Forbes Global 2000 list from 2008), there are not only financial, banking, insurance institutions, car manufacturers, and oil, food, drug, and biotechnology corporations, but increasingly also information technology producers and providers like AT\&T, Telefónica, IBM, Verizon Communications, France Telecom, Siemens, Hewlett-Packard, Samsung Electronics, Microsoft, Nippon, Nokia, China Mobile, Time Warner, Cisco Systems, and Intel. According to the Forbes Global 2000 list, fifteen of the 100 dominant corporations were active in the area of information technology in 2008.

Subject-Object Dialectic. If one applies a dialectical methodology, the rise of transnational informational capitalism is neither only a subjective nor only an objective transformation, but based on a subject-object dialectic. Objective approaches are technodeterministic and neglect how forms of labor and agency have changed; subjective approaches neglect that technology is a force that shapes and is shaped by agency. Both the technology-oriented objective and the subjective knowledge-oriented Marxist approaches are insufficient. At the same time, they are right in stressing one pole of the dialectic of a larger framework. The notion of transnational informational capitalism sublates both lines of thinking dialectically as information and networks have both an objective and a subjective aspect; they transform the means of production and its relations. Knowledge is produced, communicated, and consumed with the help of technologies, so that new knowledge can emerge that again is socialized with the help of technologies and so on. In this dialectical dynamic, knowledge and technology reinforce each other.

The search of capital for new strategies and forms of capital accumulation transforms labor in such a way that cognitive, communicative, and cooperative labor forms a significant amount of overall labor time (a development enforced by the rise of the ideology of self-discipline of "participatory management"), but at the same time this labor is heavily mediated by information technologies and produces tangible informational goods to a certain extent (as well as intangible informational services) (see Fuchs 2008a). The notion of transnational informational capitalism grasps this subject-object dialectic as it conceptualizes contemporary capitalism based on the rise of cognitive, communicative, and cooperative labor that is interconnected with the rise of technologies and goods that objectify human cognition, communication, and cooperation. Informational capitalism is based on the dialectical interconnection of subjective knowledge and knowledge objectified in information technologies. The reason I think this approach is well grounded is that dialectical thinking permits conceiving reality as complex and dynamic, which brings into question one-dimensional, discontinuous, and static-ideological accounts of reality. 


\section{The Rise of Transnational Informational Capitalism}

Some scholars prefer to speak of information capitalism (Morris-Suzuki 1997) or informational capitalism (Castells 2000; Fuchs 2005; Fuchs 2008a; Schmiede 2006a,b). Manuel Castells sees informationalism as a new technological paradigm (he speaks of a mode of development) characterized by "information generation, processing, and transmission" that have become "the fundamental sources of productivity and power" $(2000,21)$. Castells adds the idea to theories of the information society that, in contemporary society, dominant functions and processes are increasingly organized around networks that constitute the new social morphology (2000,500). Castells is a dualistic theorist; he speaks for a discontinuous approach (network society) and a more continuous one (informational capitalism) at the same time.

Some theorists criticize Castells's account as technodeterministic (see Garnham 2004). These charges are overdrawn, on the one hand, because Castells points out that his approach is based on a dialectic vision of technology and society in which technology embodies society and society uses technology (Castells 2000, $5 \mathrm{ff}$.). On the other hand, they point toward the eclectic character of Castells's works that is due to a lack of social theory (see Fuchs 2008a). Although Castells makes clear that dominant forms of capitalist production shape the rise of a new "mode of development," he does not give reasons why he has chosen this term. That can create the impression that technology is the only driving force of society. In my view, it is more appropriate and less prone to technodeterminism to speak in more conventional Marxian terms of "productive forces." Castells also contradicts himself when he argues in another passage that informationalism is the result of "new technological conditions" $(2000,21)$ and not of a restructuring of capitalism, as he argued initially. Academia is embedded in society and therefore all theories and academic thinking are likely to reflect certain interests. It is problematic that Castells presents his analysis as rather neutral and says that policy conclusions should be avoided (see Van Dijk 1999) because all academic thinking is based on axiological assumptions. In my opinion, one should criticize Castells for not suggesting political implications and for his wide neglect of his own Marxist roots, but one should not go so far as to conclude that his work is "a right-wing celebration of informational capitalism" (Jessop 2003).

On the one hand, the notion of the network society points toward important changes of capitalism. The accumulation of economic, political, and cultural capital (cf. Fuchs 2003b) is globalizing and we witness the rise of a flexible regime of accumulation (Harvey 1989). On the other hand, the concept is an ideology that obscures domination because phenomena such as structural unemployment, rising poverty, social exclusion, the deregulation of the welfare state and of labor rights, and the lowering of wages in order to maximize profits can easily be legitimized in a society where networks are seen as natural organization patterns. Hence the problems of contemporary "network society" can be presented as inevitable and as something to which people have to adapt, not as a situation that is open to fundamental criticism and requires political intervention and change (Barney 2004, 180). Steven Shaviro speaks of "soft fascism" in this context $(2003,4)$. The term 
"network society" also obscures that we live in a capitalist society that is restructuring and changing its organizational form. Networks are characteristic of all systems; they are not peculiar to contemporary Western society. The historically novel quality is that, in more and more systems (such as the economy, polity, and the Internet), transnational actors that operate on a global scale can be found. That turns them into transnational/global networks. It is more appropriate to speak of transnational/global capitalism, transnational/global network capitalism, or transnational/global informational capitalism in order to stress the dialectic of continuity and discontinuity and the role of information and new information and communication technologies in society.

Kojin Karatani (2005), 265-8) argues that just like in the development stage of imperialism, in the stage of late capitalism there is no fundamental novelty; in Capital Marx already grasped contemporary structures even before their advent, not as substance but as form. Hence not rebuke or renovation, but a return to Marx would be required today. Marx, according to Karatani, described the form of phenomena like casino capitalism, e-trade, service labor, soft labor, intellectual labor, and information administration as aspects of capitalism. The fundamental continuity for Karatani is that capital accumulation is based on surplus value, no matter if this value is based on predominantly mental or manual labor. "In this sense, capital does not care whether it gets surplus value from solid object or fluid information. So it is that the nature of capital is consistent even before and after its dominant production branch shifted from heavy industry to the information industry... What capital has to produce from the beginning are not products in and of themselves, but, more crucially, value (and surplus value)" (Karatani 2005, 267-8). For Karatani (2001), in contemporary capitalism surplus value is achieved by the compression and digitalization of communication in the circulation process, where information has become the world commodity and thus the Internet is dialectically entangled in the capitalist economy. I agree with Karatani that a rereading and rediscovery of Marxian theory is required, not its revision. However, his account stresses the continuity pole of the dialectic too much and rather neglects the emergence of new qualities of continuous structures. The emergence of informational capitalism can be consistently explained by taking a look at the role of information and intellectual labor in the Marxian concept of the development of the productive forces. Transnational informational capitalism is the result of the dialectic of continuity and discontinuity that shapes capitalist development. Surplus value, exchange value, capital, commodities, and competition are basic aspects of capitalism; how exactly such forms are produced, objectified, accumulated, and circulated is contingent and historical. They manifest themselves differently in different capitalist modes of development. In the informational mode of capitalism, surplus value production and capital accumulation manifest themselves increasingly in symbolic, "immaterial," informational commodities and cognitive, communicative, and cooperative labor. The accumulation of capital, power, and definition-capacities on a transnational scale is strongly mediated by new media. Roy Bhaskar $(1993,12)$ distinguishes between real negation $\geq$ transformative negation $\geq$ radical negation in order to stress the nondeterministic and complex character of sublation. Not all negations of negations are at the fundamental level; there are also partial sublations that are transformative, but not 
radical. The emergence of transnational informational capitalism is a transformational sublation, but not a radical one.

After the second world economic crisis in the mid-1970s, there was a transition from the Fordist mode of development to the post-Fordist mode of capitalist development. In order to increase profits, new strategies and a flexible regime of accumulation and domination (Harvey 1989) emerged. The main idea was to increase profits by putting pressure on nation-states to lower wages and by decentralizing and globalizing the production process in order to reduce wage costs as well as investment and reproduction costs of capital so that variable and constant capital would decrease, resulting in an increased production of surplus value and hence rising profits.

The increasing importance of computer networks and global network organizations is an instrumental result of capitalist development. Computer technology and the Internet were invented and introduced not in an economic, but in a military, context. The societal diffusion of these technologies occurred due to their original role in the economic restructuration of capitalism. Computer networks are the technological foundation that has allowed the emergence of global network capitalism: that is, regimes of accumulation, regulation, and discipline that are helping to base the accumulation of economic, political, and cultural capital increasingly on transnational network organizations that make use of cyberspace and other new technologies for global coordination and communication (Fuchs 2008a).

Globalization can generally be defined as the stretching of social relationships - that is, communication networks - in space-time. A globalizing social system enlarges its borders in space-time and, as a result, social relationships can be maintained across larger temporal and spatial distances (Fuchs 2003a). In modern society, processes of globalization are based on the logic of accumulation of natural resources, tools, money capital, power, and hegemony. The main problem of modern society is how to accumulate ever more capital. When an existing regime/mode of accumulation reaches its inherent limits and enters crisis, new strategies and areas of accumulation are required in order to revert to ordered processes of accumulation. Hence globalization in modern society is inherently driven by the logic of capital accumulation, which results in the appropriation and production of new spaces and systems of accumulation. The antagonism between structures and actors is characteristic for modern society (social structures are alienated from their producers: that is, they are controlled by certain groups that exclude others from control) and results in a clash of estrangement and self-determination that is characteristic for all subsystems of modern society (cf. Fuchs 2008a). The basic conflict is that many people cannot cope with the increasing complexity of the world because their lives are increasingly shaped by globally alienated structures that are out of their reach and in which they cannot participate.

Contemporary capitalism is based on a transnational organizational model. Organizations cross national boundaries; the novel aspect is that organizations and social networks are increasingly distributed worldwide, that actors and substructures are located globally and change dynamically (new nodes can be continuously added and removed), and that the flows of capital, power, money, commodities, people, and information are processed globally at high speed. Global network capitalism is a 
nomadic and dynamic system in the sense that it and its parts are permanently reorganized by changing their boundaries and including or excluding various systems by establishing links, unions, and alliances or getting rid of or ignoring those actors that do not serve or contribute to the overall aim of capital accumulation.

Network technologies like the Internet enable communication and social relations across spatial and temporal distances due to their global reach, decentralized structure, and high-speed support. Phil Graham $(2006,1,72)$ sees the high speed and extent of communication as the central characteristic of what he terms hypercapitalism. High speed is just one quantitative feature of a new quality of capitalism, a networked transnational regime of rule. It might be better to focus on qualities and not on quantities when choosing a key concept because, in dialectical thinking, the transformations that emerge from the overturn on quantitative features are decisive. A global space is constituted by the interaction of global technological systems and transnational (economic, political, cultural) organizations and institutions (cf. Amin 2004). This space is characterized by global flows of capital, power, and ideology that create and permanently recreate a new transnational regime of domination.

Some scholars argue that networks are inherently nonhierarchic and inclusive (Deleuze and Guattari 1976; Goguen and Varela 1979) whereas others say that networks are not automatically politically progressive and participatory, but can be segmented, centralized, and hierarchic (Castells 2000, 2004; Van Dijk 2006; Hardt and Negri 2005). The most general definition of a network is that it is a system of interlinked nodes. This definition does not imply full connectivity and a symmetric flow of resources. Given this definition, in a network there can be hubs and centers that are of strategic importance because they have much more direct links to and from other nodes. They store and centralize resources, controlling the flow of resources throughout the network. A network can have different degrees of centrality and hierarchy; there can be either a rather polycentric, pluralistic, and decentralized structure or central actors that dominate the movement. The degree of decentralization refers to the distribution or control of resources such as knowledge, activists, money, decision power, infrastructure, technologies, and cultural definition power.

A systemic form of centralization of property and other resources characterizes the global economy of network capitalism. If capitalism is indeed organized as a global network economy, then one has to stress that the spatial geography of this economy is devised in such a way that there is a class of central hubs (corporations, countries, cities, city zones, regions, occupational groups, classes, individuals) that controls the flows of property, money, and goods in the network, hence creates an asymmetrical, divided, exclusive economic space where the majority of people are marginalized and kept outside the network and a divided geography is created. Many people feel the effects of this rigid, economically dominated type of globalization and feel estranged because decisions that affect their lives are made by anonymous powers that they do not know and whose actors they will never meet and are physically detached from local contexts.

One example of the stratified character of transnational network capitalism is unequal access to ICTs. Access is a question of not only physical access, but also access to skills, usage capacities, meaningful usage opportunities, and opportunities for political participation (Fuchs and Horak 2008). But physical access is a foundation 
for other forms of access, hence very important. The digital divide is not "digital," but the expression of the class structure of transnational informational capitalism. One of the consequences of poverty and inequality is the digital divide. This division can be visualized by figures such as one that shows that, although Africa makes up 14.5 percent of the world population, it accounts for only 3.4 percent of the world's Internet users (Internet World Statistics, http://www.internetworldstats.com/ stats.htm, accessed 24 April 2009). Twenty of the fifty-seven African countries had access rates lower than 1 percent in 2006 (Fuchs and Horak 2008). Most African countries are excluded from informational capitalism. The United Nations considered sixteen of the twenty African countries with Internet access of less than 1 percent as ranging among the least developed countries in the world in 2006 (measured by the Human Development Index).

Network organization is a characteristic of the post-Fordist global economy: networks of firms, networks of suppliers and distributors, financial networks, strategic alliances, joint ventures, financial markets that are based on fast global flows of increasingly "immaterial" speculative capital that are transmitted and manipulated digitally by making use of network technology.

If knowledge labor is defined as producing goods and services that are primarily oriented toward cognition, communication, or cooperation, then knowledge jobs make up 44.21 percent of all wage labor in the U.S. economy (2005 data; see Fuchs 2008a, 193-200), which is the largest relative share compared to agriculture, traditional manufacturing, and nonknowledge services. Based on the same typology, 38 percent of the total U.S. value added in 2006 was produced in the knowledge sector (2.9 percent in agriculture, 16.8 percent in traditional manufacturing, 42.3 percent in the nonknowledge service sector - data by http://www.bea.gov; typology from Fuchs 2008a, 194-9). These data show that knowledge has become very important as a factor of production in surplus value production and capital accumulation.

Long-term trends show that, in the years from 1951 to 2004, the growth of the value and volume of exports was in general larger than the growth of the world gross domestic product (WTO 2005, table II.1). The total value of world exports and imports increased continuously (table II.2). The export and import shares of world exports decreased in North America, Africa, South and Central America, and Australia/New Zealand, and increased in Europe. In Asia, both shares increased in East Asian countries like China and Japan and decreased in other parts like India (table II.2). These data show that contemporary trade globalization is shaped by the emergence of a trade triad (North America, Europe, and East Asia) and the exclusion of many developing countries.

The world foreign direct investment (FDI) inward stocks as percentage of the world gross domestic product grew from 8.4 percent in 1990 to 24.8 percent in 2006, and the outward stocks from 8.7 to 26.1 percent (UNCTAD 2007, annex, table B.2). The important qualitative feature of this quantitative increase is its stratified character. FDI is highly concentrated. In 2006, 55.0 percent of the total world FDI flows came from Europe, 21.5 percent from North America, and 9.6 percent from Asia; 43.4 percent of the total inflows went to Europe, 19.7 percent to North America, and 
19.9\% to Asia (table B.1). The rest of the world, Latin America and Africa, was largely excluded, which again shows the polarized structure of contemporary globalization.

Export and investment data confirm the transnationalization hypothesis. The increase in quantity has resulted in a polarization and concentration in the form of a triadization as a new quality of economic globalization. The interconnection between informatization and globalization can be seen, for example, in the fact that services accounted for almost two-thirds of world inward FDI stock in 2005 (manufacturing 30 percent, agriculture less than 10 percent). In 1990, the share of services was 30 percent (xvi).

The economic power of transnational corporations (TNCs) can be visualized, for example, by the figure that the assets of the world's largest company, the Bank of Scotland (measured in terms of assets: US\$3,490.80 bn, Forbes Global 2000 List 2009, http: / /www.forbes.com) are larger than the GDPs of all single countries except Japan and the United States (World Bank 2009, 356-357, GDP rates for 2007).

These example data are incomplete, and it is a task of future research to expand them. They nonetheless show that there is empirical evidence that contemporary society is both informational and transnational, but its most important characteristic is that it is stratified and a class society. Therefore, it should be labeled as capitalist society. It is reasonable to describe contemporary world society as transnational informational capitalism. Most important, the data also show that this social formation is class-structured (see Fuchs 2008a). The bottom line of informational capitalism is that it is a system that has found new forms for deepening old inequalities. For instance, whereas the average profit rate has increased by 39.4 percent in the years from 1987 to 2007 among the EU15 countries (net returns on net capital stock; European Commission Annual Macro-Economic Database), the wage share has decreased by 7.5 percent in the same time span (compensation per employee as percentage of GDP at current market prices; European Commission Annual Macro-Economic Database). The result of such development is a rising income inequality as capitalist globalization globalizes only the rich and precarious living, whereas it localizes the poor.

The basic idea underlying the concept of transnational information capitalism is that the accumulation of money capital, power, and cultural definition-capacities - that is, exploitation, domination, and ideological legitimization - have become more transnational and are influenced by knowledge production (subjective aspect) and networked digital information and communication technologies (objective aspect) (see Fuchs 2008a). Transnational network capitalism has an antagonistic character; knowledge and new technologies do not have one-sided effects, but should be analyzed dialectically: They are embedded in a fundamental antagonism of capitalism, one between cooperation and competition, that has specific manifestations in the various subsystems of society (see Fuchs 2008a). The computer is a universal machine that is simultaneously a means of production, circulation, and consumption. This feature combined with networking has resulted in the emergence of the figure of the prosumer that, on the one hand, promises a new model of cooperative production and socialization of the means of production, but, on the other hand, is antagonistically subsumed under the rule of capital (Fuchs 2009, 2008b). 
The two notions of network and information are closely related but not identical (Fuchs 2008a, 2007). A network is the inner interaction structure of a complex system. It comprises parts, their relationships, and the patterns that emerge from the interactions. Information is a dynamic process comprising three aspects: internal structuring (cognition), interaction/communication, and joint action resulting in emergent qualities of the overall system (cooperation). A network can be considered the internal structure of a complex system that is the medium and outcome of the threefold information processes of cognition, communication, and cooperation. There is a dialectic of network structures and information processes.

\section{Capital Accumulation in Informational Capitalism}

The law of value does not, as claimed by autonomous Marxists, become unimportant today. In the categories of the Marxian labor theory of value, the value of a product is the objectified labor time needed for producing the good. "The value of a commodity, therefore, varies directly as the quantity, and inversely as the productiveness, of the labor incorporated in it" (Marx 1867, 54-5).

The value of a commodity is made up of the value of the necessary raw materials (constant capital), the value of the necessary labor (variable capital), and the newly generated value (surplus value): $\mathrm{V}=\mathrm{c}+\mathrm{v}+\mathrm{s}$. If knowledge is produced once, it can be copied and transported almost at no cost with the help of such media as CDs, DVDs, and the Internet. Capital is so interested in commodifying knowledge because the latter has a low value; it does not depreciate by consumption, and it can be reproduced cheaply. The sale of knowledge at prices above its economic value is the central value-theoretic mechanism in the process of accumulating capital with knowledge products.

Let us consider an example that shows that capital can make use of the specific characteristics of information in order to yield large profits with information commodities. Imagine the production of a mass software with a certain turnaround time. The production time of the necessary knowledge is best assigned to the first turnover period of capital. We assume that all copies are sold, that a profit is already achieved after the first turnaround, and that there are no interest and rent to be paid. Let the market price of one piece of software be $1190 €$. We have to distinguish the constant and variable capital in the production of knowledge $\left(c_{1}\right.$ and $\left.v_{1}\right)$ from the capital involved in the physical reproduction process $\left(c_{2}\right.$ and $\left.v_{2}\right)$. Let us also assume that at the first turnover 100,000 pieces of the commodity are produced, that $c_{1}=10$ $10^{6} €, v_{1}=5010^{6} €, c_{2}=510^{6} €, v_{2}=210^{6} €$.

The total investment costs are $6710^{6} €$. We assume a rate of surplus value of 100 percent. The mass of constant capital is $c=c_{1}+c_{2}=1510^{6}$, the mass of variable capital $v=v_{1}+v_{2}=5210^{6}$. Due to a rate of surplus value of 100 percent, the mass of surplus value produced is $s=5210^{6} €$. All copies are sold, hence the revenues are $1190^{*} 100,000=11910^{6} €$. Subtracting the investment costs from this sum results in a profit of $5210^{6} €$ in the first year. The average value of a single copy is $v=c_{d}+v_{d}+s_{d}$, where $c_{d}, v_{d}$, and $s_{d}$ describe the average proportions for one commodity of the total 
constant and variable capital as well as of the total surplus value produced. The average commodity value is

$$
v=\frac{15 \times 10^{6}}{10^{5}}+\frac{52 \times 10^{6}}{10^{5}}+\frac{52 \times 10^{6}}{10^{5}}=1190
$$

In this example, the value of the commodity equals its market price. Let's take a look at the second turnover of capital: We assume that the conditions of production, the costs, and the total amount of produced commodities remain the same. How does the profit develop? The investment costs for knowledge production do not have to be spent by the capitalists this time due to the specific characteristics of information $\left(c_{1}=0, v_{1}=0\right)$. Hence the average commodity value is reduced to

$$
v=\frac{5 \times 10^{6}}{10^{5}}+\frac{2 \times 10^{6}}{10^{5}}+\frac{2 \times 10^{6}}{10^{5}}=90
$$

This means that the average value of a single piece of software has massively decreased without a change in the conditions of production! This is due to the fact that knowledge only has to be produced once. It only has what Marx called a "moral" devaluation, but does not lose value by aging, use, or nonuse; it can be reproduced easily and at very low costs. The software is still sold at $1190 €$, hence the profit increases from $5210^{6} €$ to $11210^{6} €$. This amounts to an increase of average profit from $520 €$ to $1120 €$ per commodity and an increase of the profit rate from 0.78 to 16 (profit rate $=$ profit $/(c+v)$ )! This example shows that the value of a piece of software is much lower than its market price and that the specific characteristics of knowledge favor capital accumulation in the knowledge and software industry.

\section{Conclusion}

Concepts like knowledge, information, postmodern, postindustrial, Internet, and network society fail to grasp the dialectic of continuity and discontinuity of society. They construct the changes connected to new media as radical novelties and ignore the continuing dominance of capitalist structures. In order to stress that capital accumulation is transformed by the rise of knowledge and information technologies and the transnational spatial model connected to the flexible regime of accumulation, I have suggested using notions like transnational network capitalism, transnational informational capitalism, or transnational knowledge capitalism as key concepts for describing contemporary society. Capital accumulation with the help of knowledge commodities is based on the specific characteristics of information in knowledge capitalism: it is generally not used up by its manifold usage, it expands during its usage, it can be compressed, it can replace other economic resources, it can be transported at the speed of light over the global information networks, and the costs of reproducing information are generally very low and are further diminished by technological innovations and progress. Knowledge as commodity can be produced and diffused very cheaply. The mechanism for gaining profit from information 
commodities is that such goods are sold at prices that are much higher than their values.

\section{References}

Adorno, T. W. 1970. Ästhetische Theorie. Frankfurt/Main: Suhrkamp.

Amin, A. 2004. Regulating economic globalization. Transactions of the Institute of British Geographers 29 (2): 217-33.

Barney, D. 2003. The network society. Cambridge: Polity.

Bell, D. 1976. The coming of post-industrial society. New York: Basic Books.

Bhaskar, R. 1993. Dialectic: The pulse of freedom. London: Verso.

Castells, M. 2000. The information age: Economy, society and culture. Vol. 1, The rise of the network society. 2nd ed. Malden, Mass.: Blackwell.

. 2004. The information age: Economy, society and culture. Vol. 2, The power of identity. 2nd ed. Malden, Mass.: Blackwell.

Dawson, M., and J. B. Foster. 1998. Virtual capitalism. In Capitalism and the information age, ed. R. W. McChesney, E. M. Wood and J. B. Foster, 51-67. New York: Monthly Review Press.

Dean, J. 2005. Communicative capitalism: Circulation and the foreclosure of politics. Cultural Politics 1 (1): 51-74.

Deleuze, G., and F. Guattari. 1976. Rhizome. Paris: Les Éditions de Minuit.

Deutsch, K. 1983. Soziale und politische Aspekte der Informationsgesellschaft. In Die Zukunft der Informationsgesellschaft, ed. P. Sonntag, 68-88. Frankfort/Main: Haag and Herchen.

Drucker, P. 1969. The age of discontinuity. London: Heinemann.

Dyson, E., G. Gilder, G. Keyworth, and A. Toffler. 1994. Cyberspace and the American dream: A Magna Carta for the knowledge age. Future Insight 1: 2.

Fitzpatrick, T. 2002. Critical theory, information society and surveillance technologies. Information. Communication and Society 5 (3): 357-78.

Fuchs, C. 2003a. Globalization and self-organization. tripleC 1 (2): 105-69. http:// www.triple-c.at/.

2003b. Some implications of Pierre Bourdieu's works for a theory of social self-organization. European Journal of Social Theory 6 (4): 387-408.

. 2004. The antagonistic self-organization of modern society. Studies in Political Economy, no. 73: 183-209.

. 2005. Emanzipation! Technik und Politik bei Herbert Marcuse. Aachen: Shaker.

2007. Transnational space and the "network society." 21st Century Society 2 (1): $49-78$.

. 2008a. Internet and society: Social theory in the information age. New York: Routledge.

2008b. Review of Wikinomics: How mass collaboration changes everything,

by D. Tapscott and A. D. Williams. International Journal of Communication 2:

1-11. http://www.ijoc.org/ojs/index.php/ijoc/article/viewPDFInterstitial/250/ 125.

2009. Information and communication technologies and society: A contribution to the critique of the political economy of the Internet. European Journal of Communication 24 (1): 69-87. 
Fuchs, C., and E. Horak. 2008. Africa and the digital divide. Telematics and Informatics 25 (2): 99-116.

Garnham, N. 2004. Information society theory as ideology. In The information society reader, ed. F. Webster. New York: Routledge.

Glotz, P. 1999. Die beschleunigte Gesellschaft. Kulturkämpfe im digitalen Kapitalismus. Munich: Kindler.

Goguen, J. A., and F. A. Varela. 1979. Systems and distinctions: Duality and complementarity. International Journal of General Systems 5 (1): 31-43.

Golding, P. 2000. Forthcoming features: Information and communications technologies and the sociology of the future. Sociology 34 (1): 165-84.

Graham, P. 2006. Hypercapitalism. New York: Peter Lang.

Hardt, M., and A. Negri. 2005. Multitude. London: Hamish Hamilton.

Harvey, D. 1989. The condition of postmodernity. London: Blackwell.

Haug, W. F. 2003. High-Tech-Kapitalismus. Hamburg: Argument.

Jessop, B. 2003. Informational capitalism and empire: The post-Marxist celebration of U.S. hegemony in a new world order. Studies in Political Economy 71/72: 39-58.

Karatani, K. 2001. The principles of the New Associationist Movement (NAM). http:// www.clas.ufl.edu/users/jmurphy/Karatani01file/NAM.Principles.html (accessed 21 March 2007).

2005. Transcritique: On Kant and Marx. Cambridge, Mass.: MIT Press.

Knoche, M. 1999. Media economics as a subdiscipline of communication science. In The German communication yearbook, ed. H.-B. Brosius and C. Holtz-Bacha, 60-100. Cresskill, N.J.: Hampton Press.

Lyotard, J.-F. 1984. The postmodern condition. Manchester: Manchester University Press.

Machlup, F. 1962. The production and distribution of knowledge in the United States. Princeton, N.J.: Princeton University Press.

Marx, K. 1867. Das Kapital. Band 1. Marx-Engels-Werke, Vol. 23. Berlin: Dietz.

McChesney, R. W. 1998. The political economy of global communication. In Capitalism and the information age, ed. R. W. McChesney, E. M. Wood and J. B. Foster, 1-26. New York: Monthly Review Press.

Morris-Suzuki, T. 1997. Capitalism in the information age. In Cutting edge, ed. J. Davis, T. Hirschl and M. Stack, 57-71. London: Verso.

Otto, P., and P. Sonntag. 1985. Wege in die Informationsgesellschaft. Munich: dtv.

Piore, M. J., and C. Sabel. 1984. The second industrial divide: Possibilities for prosperity. New York: Basic Books.

Porat, M. 1977. The information economy. Washington, D.C.: U.S. Department of Commerce.

Schiller, D. 2000. Digital capitalism. Cambridge, Mass.: MIT Press.

Schmiede, R. 2006a. Knowledge, work and subject in informational capitalism. In Social informatics: An information society for all?, ed. J. Berleur, M. I. Nurminen and J. Impagliazzo, 333-54. New York: Springer.

2006b. Wissen und Arbeit im "Informational Capitalism." In Informatisierung der Arbeit-Gesellschaft im Umbruch, ed. A. Baukrowitz, 455-88. Berlin: Edition Sigma.

Shaviro, S. 2003. Connected: Or what it means to live in the network society. Minneapolis: University of Minnesota Press.

Stehr, N. 1994. Arbeit, Eigentum und Wissen. Frankfurt/Main: Suhrkamp. 2002a. A world made of knowledge. Paper presented at "New Knowledge and New Consciousness in the Era of the Knowledge Society," held in Budapest, 31 
January. http://www.crsi.mq.edu.au/pdfworddocs/worldknowledge.pdf (accessed 24 January 2007).

2002b. Knowledge and economic conduct. Toronto: University of Toronto Press.

Thrift, Nigel. 2005. Knowing capitalism. London: Sage.

United Nations Development Programme (UNDP). 2007. United Nations Human Development Report 2007/2008. New York: Palgrave Macmillan.

Van Dijk, J. 1999. The one-dimensional network society of Manuel Castells. New Media and Society 1 (1): 127-38. . 2006. The network society. 2nd ed. London: Sage.

Vercellone, C. 2007. From formal subsumption to general intellect: Elements from a Marxist reading of the thesis of cognitive capitalism. Historical Materialism 15 (1): 13-36.

Virno, P. 2004. A grammar of the multitude. New York: Semiotext(e).

Webster, F. 2002a. The information society revisited. In Handbook of new media, ed.

L. A. Lievrouw and S. Livingstone, 255-66. London: Sage. . 2002b. Theories of the information society. New York: Routledge.

World Bank. 2009. World development report 2009. Washington, DC: World Bank.

World Trade Organization (WTO). 2005. International trade statistics. Lausanne: WTO. 